\title{
The association of leptin gene polymorphism with reproductive usefulness and selected blood biochemical indicators of hybrid sows (Polish Large White $\times$ Polish Landrace)
}

\author{
Agata Wierzchowska, Anita Kołodziej-Skalska, Dorota Napierała, Maria Kawęcka, \\ Eugenia Jacyno
}

West Pomeranian University of Technology, Department of Pig Breeding, Animal Feeding and Food, Szczecin, Poland

Received September 30, 2011

Accepted September 19, 2012

\begin{abstract}
Rapid developments in the field of molecular genetics have led to new possibilities to identify polymorphic genes and to detect quantitative trait loci with major effects on economically important reproduction traits. Our study has defined the influence of polymorphism at position 3469 of the leptin gene on reproductive performance in sows as well as on selected blood biochemical indices in pregnant sows The research involved 173 multiparous sows after the second and third farrowing, crossbreds of Polish Large White and Polish Landrace breeds. The collected data on reproductive performance of sows concerned the number of live births, the number of weaned piglets and the length of weaning-to-estrus interval in the sows. Parities from the first to the fourth were analysed. A sample of blood was collected from each sow in the third month of pregnancy in order to isolate and then analyse DNA with the use of the PCRRFLP methods. Blood biochemical analyses were performed as well. Two alleles of the leptincoding gene ( $\mathrm{T}$ and $\mathrm{C}$ ) were found in examined herd. In the second parity, where the live birth number was concerned, the difference between the CC (10.4) and TT (9.0) leptin genotypes proved to be significant $(P \leq 0.05)$. Analyses of blood biochemical indices revealed virtually no significant differences between the genotypes compared. However, it was noted that the glucose concentration was the highest in the sows with TT genotype and the lowest in the sows with CC genotype.
\end{abstract}

Genotype, QTL, single nucleotide polymorphism, reproductive traits, blood biochemical indicators

Among production traits, reproductive performance, especially the number of piglets per litter, is fundamental for the profitability of pig production. However, improvement of these traits in pigs by traditional selective breeding has proved to be difficult due to low heritability for litter size, but genetic variance for reproductive traits is large. Many candidate genes were found by considering the gene function itself or high linkage with functional genes, which could be possible because of advanced molecular technique.

One of the QTLs (Quantitative Trait Loci) gene candidates that has emerged as an important player in reproduction, is leptin gene. The progress in defning the role in food intake and energy expenditure, points out leptin to be a link between fat and fertility. Several polymorphisms of the pig $L E P$-gene have been identified to date, the best documented of which is a silent mutation in the exon III at position T3469C (Kennes et al. 2001). The previous research results have not as yet definitely confirmed the connection between the aforementioned LEP gene polymorphism and the reproductive-traits variability.

For this reason, the present research was undertaken in order to verify a potential link between the mutation and breeding value, as well as between selected blood biochemical indices in pregnant sows. 


\section{Materials and Methods}

A herd of 173 sows originating from the crossing of Polish Large White (PLW) and Polish Landrace (PL) breeds was used in this study. The maintenance conditions as well as the nutritional conditions were uniform for all animals. The sows were fed according to the Nutritional Standards (1993), with all-mash feed, twice a day, and kept in group pens, 8 animals in each. They were all mated to PIC (Pig Improvement Company) boars.

A sample of blood was taken on a single day from pregnant sows (third month of pregnancy) from the jugular vein, $4 \mathrm{~h}$ after feeding time. The collected material was stored in a vacuum test-tube containing $\mathrm{K}_{3}$ EDTA (acting as anticoagulant) and transported to the laboratory of the Department of Pig Breeding, Animal Feeding and Food at the West Pomeranian University of Technology in Szczecin. The data pertaining to the reproductive performance of the individuals under examination (to the fourth litters inclusive) were also collected. The data included the number of born-alive (NBA), the number of piglets weaned (NPW), and the length of weaning-toestrus interval (WEI).

DNA was isolated from whole-blood samples and the $L E P$-gene polymorphism was analysed by means of a kit Epicentre MasterPureTM Genomic DNA Purification Kit for Blood (Epicentre Technologies ${ }^{\circledR}$, Madison, USA).

The polymorphic fragments of the selected genes were subjected to a molecular analysis in which the PCRRFLP method was applied with the following 152-bp primers pair: F: 5'-TGCAGTCTGTCTCCTCCAAA-3' and R: 5'-CGATAATTGGATCACATTTCTG-3'.

The PCR reaction mixture ratio (per sample) was as follows: $0.3 \mu$ l genomic DNA, $0.5 \mu 1$ of each primer, $1 \mu \mathrm{l}$ of each dNTP, $0.6 \mu 1 \mathrm{MgCl}_{2}, 0.25 \mu \mathrm{l}$ of Taq DNA polymerase (MBI Fermentas Burlington, Ontario, Canada) in a standard $1 \mu \mathrm{l}$ PCR buffer. The mixture as a whole was complemented with $5.4 \mathrm{ml}$ of demineralised water. The reaction temperature conditions included the following steps: initial denaturation $\left(3 \mathrm{~min}\right.$ at $\left.95^{\circ} \mathrm{C}\right), 33$ denaturation cycles $\left(40 \mathrm{~s}\right.$ at $\left.95^{\circ} \mathrm{C}\right)$, annealing $\left(1 \mathrm{~min}\right.$ at $\left.55^{\circ} \mathrm{C}\right)$, extension $\left(1 \mathrm{~min}\right.$ at $\left.72{ }^{\circ} \mathrm{C}\right)$. The final synthesis was conducted for $5 \mathrm{~min}$ at $72^{\circ} \mathrm{C}$.

The amplified fragment was digested with a specific endonuclease Hinfl in order to identify the polymorphic site at position T3469C. After incubation at $37^{\circ} \mathrm{C}$ the PCR products were separated in agarose gel electrophoresis (agarose concentration 2\%). As a result of the amplified PCR products digestion with the Hinfl enzyme 2 alleles $(\mathrm{C}$ and $\mathrm{T})$ were obtained which were responsible for producing three genotypes: TT, TC and CC.

The blood had to be centrifuged in order to obtain the serum so that biochemical analyses could be carried out. BioMaxim reagents were used to determine total protein concentration, glucose concentration, total cholesterol and its high density lipoproteins (HDL) fraction concentration, and tryglicerides concentration. The low density lipoproteins (LDL) values were calculated according to the Friedewald formula (Broncel 2010):

LDL cholesterol fraction $(\mathrm{mg} / \mathrm{dl})=$ total cholesterol $(\mathrm{mg} / \mathrm{dl})-$ HDL cholesterol fraction $(\mathrm{mg} / \mathrm{dl})-$ [triglycerides $(\mathrm{mg} / \mathrm{dl}) / 5]$

The values obtained were subjected to statistical calculations, specifically one-factor analysis of variance. For this purpose STATISTICA PL ver. 9.0 (StatSoft Inc. 2009) software package was used. The significance of differences between groups was verified with the Duncan multiple range test.

The following equation was used: $y_{i j}=\mu+a_{i}+e_{i j}$

$\mathrm{y}_{\mathrm{ij}}$ - observed value, $\mu$ - overall mean, $\mathrm{a}_{\mathrm{i}}$ - effect of $\mathrm{i}$-th genotype (i=TT, TC, CC), $\mathrm{e}_{\mathrm{ij}}$ - random residual effect.

\section{Results}

The presence of two leptine-coding alleles ( $\mathrm{T}$ and $\mathrm{C}$ ) in the sow herd under examination was determined. The alleles were responsible for producing three genotypes: TT, TC and $\mathrm{CC}$ (Table 1). The $\mathrm{T}$ allele frequency was 0.62 , while the $\mathrm{C}$ allele frequency was 0.38 . In the sow herd, 54 TT-genotype sows $(31 \%)$ were identified, as compared to 105 TCgenotype sows $(61 \%)$ and 14 CC-genotype sows (8\%).

Table 1. The frequency of leptin gene alleles and genotypes in the studied sow herd (crossbreed of Polish Large White and Polish Landrace)

\begin{tabular}{lccccc}
\hline & \multicolumn{5}{c}{ Gene $L E P /$ Hinf } \\
\cline { 2 - 6 } & \multicolumn{3}{c}{ Genotype } & \multicolumn{4}{c}{ Alleles } \\
\cline { 2 - 6 } & $T T$ & $T C$ & $C C$ & $C$ & $T$ \\
\hline Number & 54 & 105 & 14 & 0.38 & 0.62 \\
Frequency & 0.31 & 0.61 & 0.08 & & \\
\hline
\end{tabular}

$L E P / H i n f \mathrm{I}-$ analysis of the leptin gene polymorphism with applying PCR-RFLP method using the Hinfl restriction enzyme

As shown in Table 2, differences in the sows' reproductive performance indicators between the compared LEP-gene genotypes did not reach the standard level of significance in the first, third, and fourth parity, whereas in the second parity, the live birth number differences between the genotypes CC (10.4) and TT 
Table 2. Mean values and standard errors of the examined reproductive usuefulness parameters in the studied sow herd, depending on the leptin genotypes specified for each parity

\begin{tabular}{|c|c|c|c|c|c|c|c|}
\hline \multirow{3}{*}{ Parity } & \multirow{3}{*}{ Trait } & \multicolumn{6}{|c|}{ Genotype $L E P$} \\
\hline & & \multicolumn{2}{|l|}{$T T$} & \multicolumn{2}{|l|}{$T C$} & \multicolumn{2}{|l|}{$C C$} \\
\hline & & $\overline{\mathrm{x}}$ & $\mathrm{s}$ & $\overline{\mathrm{x}}$ & $\mathrm{s}$ & $\overline{\mathrm{x}}$ & $\mathrm{s}$ \\
\hline \multirow[t]{4}{*}{ I } & $\mathrm{N}$ & 54 & & 105 & & 14 & \\
\hline & NBA & 9.2 & 2.09 & 8.9 & 2.60 & 8.4 & 2.17 \\
\hline & NPW & 9.0 & 2.25 & 8.4 & 2.92 & 8.2 & 2.04 \\
\hline & WEI & 29.0 & 42.08 & 24.2 & 42.68 & 32.5 & 43.73 \\
\hline \multirow[t]{4}{*}{ II } & $\mathrm{N}$ & 53 & & 102 & & 14 & \\
\hline & NBA & $9.0^{\mathrm{a}}$ & 2.66 & 9.4 & 2.08 & $10.4^{\mathrm{b}}$ & 0.93 \\
\hline & NPW & 8.7 & 2.25 & 9.0 & 2.0 & 9.4 & 1.08 \\
\hline & WEI & 21.6 & 27.59 & 32.3 & 38.67 & 27.1 & 45.84 \\
\hline \multirow[t]{5}{*}{ III } & $\mathrm{N}$ & 48 & & 101 & & 13 & \\
\hline & NBA & 9.7 & 2.28 & 9.5 & 2.18 & 10.2 & 1.48 \\
\hline & NPW & 9.3 & 1.78 & 9.1 & 2.03 & 9.8 & 1.30 \\
\hline & $\mathrm{N}$ & 47 & & 101 & & 13 & \\
\hline & WEI & 19.7 & 24.30 & 19.3 & 33.02 & 24.8 & 42.15 \\
\hline \multirow[t]{4}{*}{ IV } & $\mathrm{N}$ & 30 & & 68 & & 7 & \\
\hline & NBA & 10.4 & 1.33 & 10.1 & 1.99 & 10.3 & 1.80 \\
\hline & NPW & 9.3 & 1.28 & 9.3 & 1.66 & 9.1 & 1.46 \\
\hline & WEI & 23.5 & 30.96 & 19.1 & 31.46 & 4.5 & 0.55 \\
\hline
\end{tabular}

$\mathrm{N}$ - the number of the examined sows with a particular genotype (specimen); NBA - the number of born-alive; $\mathrm{NPW}$ - the number of piglets weaned; WEI - weaning-to-estrus interval; a,b - a significant difference with $P \leq 0.05$.

Table 3. Mean values and standard errors of the selected blood biochemical indices in the studied sow herd, depending on the leptin genotypes

\begin{tabular}{|c|c|c|c|c|c|c|}
\hline \multirow{5}{*}{ Trait (mg/dl) } & \multicolumn{6}{|c|}{ Genotype $L E P$} \\
\hline & \multirow{3}{*}{\multicolumn{2}{|c|}{$\mathrm{n}=54$}} & \multirow{3}{*}{\multicolumn{2}{|c|}{$\begin{array}{c}T C \\
\text { Number of examined sows } \\
n=105\end{array}$}} & \multirow{2}{*}{\multicolumn{2}{|c|}{$C C$}} \\
\hline & & & & & & \\
\hline & & & & & \multicolumn{2}{|c|}{$\mathrm{n}=14$} \\
\hline & $\overline{\mathrm{x}}$ & $\mathrm{s}$ & $\overline{\mathrm{x}}$ & $\mathrm{s}$ & $\bar{x}$ & $\mathrm{~s}$ \\
\hline Triglycerides & 39.6 & 15.5 & 34.2 & 14.6 & 38.5 & 8.7 \\
\hline Protein & 8.0 & 0.90 & 7.9 & 0.68 & 7.8 & 0.68 \\
\hline Chol DST & 67.7 & 10.23 & 66.0 & 11.75 & 65.3 & 9.84 \\
\hline HDL Chol & 27.8 & 7.66 & 27.5 & 6.26 & 25.6 & 2.85 \\
\hline LDL Chol & 47.8 & 12.07 & 45.3 & 12.48 & 47.4 & 9.76 \\
\hline Glucose & $61.0^{\mathrm{Aa}}$ & 10.94 & $56.90^{\mathrm{b}}$ & 11.75 & $54.7^{\mathrm{B}}$ & 8.70 \\
\hline
\end{tabular}

Chol DST - total cholesterol concentration; HDL Chol - high density lipoprotein fraction cholesterol; LDL

Chol - low density lipoprotein fraction cholesterol; ${ }^{\mathrm{a}, \mathrm{b}}$ - a significant difference with $P £ 0.05 ;^{\mathrm{A}, \mathrm{B}}$ - a significant difference with $P \leq 0.01$

(9.0) proved to be significant $(P \leq 0.05)$. The TC sows had on average 9.4 piglets in their second parity. The tendency for a greater litter size in the $\mathrm{CC}$ sows as compared to the TC and TT sows held steady at the third parity, but in this case their superiority was not statistically proved. 
No significant differences between the compared genotypes concerning blood biochemical indices were revealed in the sow herds under examination, apart from glucose concentration (Table 3). The highest values were noted in the TT sows $(61.0 \mathrm{mg} / \mathrm{dl})$, the lowest in the CC sows $(54.7 \mathrm{mg} / \mathrm{dl})$. The intermediate value $(56.9 \mathrm{mg} / \mathrm{dl})$ of the blood glucose concentration was noted in the TC sows. There was a significant difference in glucose concentration $(P \leq 0.05)$ between this group of sows and the TT sows.

\section{Discussion}

The genotype distribution and statistical analysis showed that the highest values for the stated litters were noted in the TT sows. The obtained results were different compared to results of other researchers concerning the influence of the analysed polymorphic site on the selected reproductive traits. One study was carried out by Terman (2005) on a herd of 408 Polish Large White x Polish Landrace crossbreds. It demonstrated the TCgenotype individuals to be characterised by the highest values of the traits analysed in the litters: first, third, fourth and further. In Terman's study (2005) only in the second parity the highest values for the live birth number and for the number of the piglets weaned were noted in the LEP CC-genotype sows (10.40 and 10.30, respectively). The author reported superiority of the CC sows. Stępień-Poleszak et al. (2009) also showed considerable prevalence of allele T LEP gene in the examined gilts population of Line 990 but heterozygotes appeared with a very low frequency of 0.12 .

In our study an attempt was undertaken to analyse the marked variants of leptin gene influence on the selected blood biochemical indices in pregnant sows at an early stage of pregnancy. Mean triglycerides concentration in the sows group under study was $37.4 \mathrm{mg} / \mathrm{dl}$. The value is lower than the predicted normal range for grown pigs which is $41-83 \mathrm{mg} / \mathrm{dl}$ (Winnicka 2004). The author states the total protein concentration in the pigs serum to be within the 5.9-7.4 mg/dl limits. In the examined sows the indicator had a slightly higher value $(7.9 \mathrm{mg} / \mathrm{dl})$. In the analyses performed by Friendship et al. (1984) the protein concentration in the serum of sows at early and middle stages of pregnancy oscillated within the range of 6.5 to $9.0 \mathrm{mg} / \mathrm{dl}$.

Total cholesterol concentration in the researched sows' serum was $66.3 \mathrm{mg} / \mathrm{dl}$ on average. The value fits within the range of the normal cholesterol concentration as provided by Winnicka (2004). The lower limit of the norm is $19.4 \mathrm{mg} / \mathrm{dl}$, and its upper limit is $81.3 \mathrm{mg} / \mathrm{dl}$. The results collected are in agreement with the results of other authors researching cholesterol concentrations in pregnant sows (Friendship et al. 1984). The level of LDL cholesterol in the sows' serum observed in the presented research was on average $46.8 \mathrm{mg} / \mathrm{dl}$, whereas for the HDL fraction the mean value was $27.0 \mathrm{mg} / \mathrm{dl}$. According to the research performed by Klocek et al. (2001) the mean LDL cholesterol level in serum of sows of various breeds was $33.2 \mathrm{mg} / \mathrm{dl}$.

The mean value of glucose blood concentration in the studied sows which is $57.5 \mathrm{mg} / \mathrm{dl}$ fits within normal values $(45-100 \mathrm{mg} / \mathrm{dl})$ for grown pigs as presented by Winnicka (2004). According to the data collected in research by Friendship et al. (1984) blood glucose concentration in sows at an early stage of pregnancy had values between 52.2 and $106.2 \mathrm{mg} / \mathrm{dl}$. Kemp et al. (1996) have demonstrated, that while pregnant, sows tend to have a lower tolerance of glucose and are prone to diabetes, similarly to humans. The lower tolerance of glucose during pregnancy is suspected to cause a higher mortality rate of piglets and their higher birth weight. Cozler et al. (1998) in turn point out a connection between lower tolerance of glucose and obesity in pigs.

The sows with the TT LEP-genotype were characterised by the highest values of the examined indicators. The differences were clear, especially regarding glucose concentrations. For that indicator the differences were proved to be significant $(P \leq 0.01)$. 
Blood glucose concentration in the individuals with the TT genotypes was significantly higher compared to the CC homozygotes. The value of this difference was $6.3 \mathrm{mg} / \mathrm{dl}$. However, compared to the heterozygotes, the difference was smaller $(4.1 \mathrm{mg} / \mathrm{dl})$, but it was also significant $(P \leq 0.05)$. Cholesterol concentration was more or less similar in females with different genotypes, although the LDL fraction concentration was over $3 \mathrm{mg} / \mathrm{dl}$ lower in the heterozygote sows regarding the gene researched.

However, considering some differences between the results of this study and results of different authors, further analysis of the researched polymorphic site in leptin gene influence on the reproductive performance and glucose concentration in sows should be carried out on a larger population of animals to verify the final conclusions.

\section{References}

Broncel M 2010: Current criteria of recognizing dyslipideamia. Target concentrations of lipides in heart and vessels' diseases. Cardiol Based On Fact 1: 15-26

Cozler Le Y, David C, Beaumal V, Johansen S, Dourmad JY 1998: Effect of the feeding level during rearing on performance of Large White gilts. Part 2: effect on metabolite profiles during gestation and lactation, and on glucose tolerance. Reprod Nutr Dev 38: 377-390

Friendship RM, Lumsden JH, McMillan I, Wilson MR 1984: Hematology and biochemistry reference values for ontario swine. Can J Comp Med 48: 390-393

Kemp B, Soede NM, Vesseur PC, Helmond FA, Spoorenberg JH, Frankena K 1996: Glucose tolerance of pregnant sows is related to postnatal pig mortality. J Anim Sci 74: 879-885

Kennes YM, Murphy BD, Pothier F, Palin MF 2001: Characterization of swine leptin (LEP) polymporphisms and their association with production traits. Anim Gen 32: 215-218

Klocek C, Koczanowski J, Migdał W, Nowicki J, Kalinowska B 2001: Sows reproduction parameters in relation to blood cholesterol level. The Anim Biol 3: 133-137

Polish Norm 1993: Polish Norm of Pigs Nutrition 1993. Institute of Animal Physiology and Nutrition of the Polish Academy of Sciences in Jabłonna (in Polish), pp. 1-87

StatSoft Inc. 2009. STATISTICA (data analysis sofware system) PL version 9.0. www.statsoft.com

Stępień-Poleszak D, Pietruszka A, Kawęcka M 2009: Effect of leptin gene polymorphism on fattening and slaughter value of line 990 gilts. Acta Vet Brno 78: 267-272

Terman A 2005: Effect of the polymorphism of prolactin receptor (PRLR) and leptin (LEP) genes on the litter size in Polish pigs. J Anim Breed Gen 122: 400-404

Winnicka A 2004: Referential values of basic laboratory tests in the veterinary science. SGGW publishing company, the III edition, Warsaw, pp. 17-70 